by 7.5 and 30 minutes respectively but were never $<7.5$ $\mu \mathrm{u} . / \mathrm{ml}$. in Case 3. The insulin responses to the oral glucose loads given postoperatively were normal in all three cases. The half-times for the disappearance of insulin from the circulation were 1.6, 4.8, and 12.9 minutes in Cases 1,2 , and 3 respectively. Fig. 2 shows the results of immunoassays on the samples containing the highest levels of insulin in each case, after dilution to $1: 21: 4$, and $1: 8$. The samples from Cases 1 and 2 showed the expected levels on dilution-that is, behaved immunologically like the human insulin standardwhile the sample from Case 3 failed to assay in the same way on dilution.

\section{Discussion}

The rates of disappearance of endogenous insulin in Cases 1 and 2 were very fast, and were similar to those previously described in normal subjects given porcine insulin (Stimmler, 1967; Stimmler et al., 1969). These rates are also compatible with a theoretical prediction of insulin disappearance rate based on the known clearances of insulin by various parts of the body (Stimmler, 1966). The fall of plasma insulin to zero temporarily in Cases 1 and 2 suggests that there was no, or very little, basal insulin secretion from normal islet tissue at that time which could have interfered with the estimates of half-time in these cases, but such interference could have occurred in Case 3, in whom insulin levels did not fall to zero. Mild hyperglycaemia, however, did develop later that day in this case, suggesting some suppression of normal islet cell function, so that the finding of a slower rate of disappearance could also have been due to the presence of immunoactive material in the plasma different from the standard human insulin, which could not therefore be assayed correctly. Further studies are in progress and will be reported in due course.

We are grateful to Dr. A. S. Mason, Dr. A. Jackson, Dr. A. Robinson, Dr. M. A. Floyer, and Mr. J. E. Richardson for allowing us to study patients under their care and to Professor I. Doniach and Dr. C. Brown for the pathological reports.

\section{REFERENCES}

Berson, S. A., Yalow, R. S., Bauman, A., Rothschild, M. A., and Newerly, K. (1956). Fournal of Clinical Investigation, 35, 170

Hoffman, W. S. (1937). Fournal of Biological Chemistry, 120, 51.

Morgan, C. R., and Eazarow, A. (1963). Diabetes, 12, 115.

Samols, E., and Marks, V. (1966), Lancet, 2, 700.

Stimmler, L. (1966). Lancet, 2, 1078.

Stimmler, L. (1967). Diabetes, 16, 652.

Stimmler, L., Mashiter, K., Boucher, B. J., and Meadow, S. R. (1969) Clinical Science, 37, 371 .

Williams, R. F., Gleason, R. E., and Soeldner, J. S. (1968). Metabolism, 17,1025 .

\title{
Contact Dermatitis in Home Helps Following the Use of Enzyme Detergents
}

\author{
CHRISTINA F. J. DUCKSBURY,* M.B., CH.B., D.P.H.; V. K. DAVE, $\dagger$ M.B., B.CH., M.R.C.P.
}

Cummary: Twelve women in the home help service in Nottingham developed dermatitis after using enzyme detergents. A survey based on a questionary showed an incidence of $5 \%$ among those using them. The enzyme appears to act as a primary irritant.

\section{Introduction}

In July 196912 home helps employed by the City of Nottingham Health Department complained of acute and persistent dermatitis of the hands after using enzyme washing powders. All were subsequently examined at the dermatological department of the Nottingham General Hospital, where the diagnosis of dermatitis was confirmed. As similar cases may be occurring in other areas, this account of the outbreak may be of general interest.

\footnotetext{
* Senior Medical Officer, City of Nottingham.

† Registrar in Dermatology, Nottingham General and City Hospitals.
}

\section{Patch Tests}

All the patients had patch tests carried out on the upper part of the back with $0.1 \%$ solution in water each of Ariel, Daz, and Fairy Snow. Distilled water was used as a control. 
TABLE I.-Summary of Clinical Features of the 12 Cases

\begin{tabular}{|c|c|c|c|c|c|c|c|c|}
\hline $\begin{array}{l}\text { Case } \\
\text { No. }\end{array}$ & Age & $\begin{array}{c}\text { No. of Years } \\
\text { in Home Help } \\
\text { Service }\end{array}$ & Previous Dermatitis & \begin{tabular}{|c|} 
No. of Times \\
Enzyme \\
Detergent \\
Used
\end{tabular} & $\begin{array}{l}\text { Interval Between } \\
\text { Initial Use } \\
\text { of Enzyme } \\
\text { Detergent and } \\
\text { Onset of } \\
\text { Symptoms }\end{array}$ & Clinical Features & $\begin{array}{l}\text { Minimum } \\
\text { Duration of } \\
\text { Dermatitis }\end{array}$ & $\begin{array}{l}\text { Period of } \\
\text { Sick Leave } \\
\text { Due to } \\
\text { Dermatitis }\end{array}$ \\
\hline 1 & 57 & 16 & None & $\begin{array}{l}\text { Once } \\
\text { (Ariel) }\end{array}$ & $2-4$ hours & $\begin{array}{l}\text { Onset with irritation, blistering, } \\
\text { and swelling of hands }+++; \\
\text { dorsum of hands and } R \text {. fore- } \\
\text { arm affected }\end{array}$ & 10 weeks + & None \\
\hline 2 & 60 & 9 & None & $\begin{array}{l}\text { Once } \\
\text { (Ariel) }\end{array}$ & 3-5 hours & $\begin{array}{l}\text { Onset with irritation, blistering, } \\
\text { and swelling of hands }++++; \\
3 \text { days later dermatitis of } \\
\text { dorsum of fingers and hands, } \\
\text { which subsequently spread to } \\
\text { affect forearms }\end{array}$ & 23 weeks + & 19 weeks \\
\hline 3 & 55 & 7 & $\begin{array}{l}1 \text { year ago, dermatitis of index } \\
\text { and middle fingers both } \\
\text { hands } 3-4 \text { weeks. Off work for } \\
3 \text { weeks. Clear since }\end{array}$ & $\begin{array}{c}\text { Once } \\
\text { (Radiant) }\end{array}$ & 3-6 hours & $\begin{array}{l}\text { Onset with irritation of hands } \\
\text { and swelling }+++; \text { blister- } \\
\text { ing of dorsum of hands and } \\
\text { subsequent dermatitis }\end{array}$ & 8 weeks + & 2 weeks \\
\hline 4 & 40 & 1 & $\begin{array}{l}9 \text { months ago, irritation and } \\
\text { blistering of hands for } 3-4 \\
\text { weeks. Not off work. Clear } \\
\text { since }\end{array}$ & $\begin{array}{l}\text { Once } \\
\text { (Ariel) }\end{array}$ & 3-6 hours & $\begin{array}{l}\text { Onset with irritation }+++ \text {; } \\
1 \text { day later blistering of } \\
\text { hands with swelling. Derma- } \\
\text { titis of distal half of dorsum }\end{array}$ & 19 weeks + & 15 weeks \\
\hline 5 & 47 & 3 & None & $\begin{array}{l}\text { Once } \\
\text { (Ariel) }\end{array}$ & 1-2 days & $\begin{array}{l}\text { of hands and nngers, } \mathrm{K} .>\mathrm{L} . \\
\text { Iritation and swelling of fingers } \\
++ \text { + with blistering. Derma- } \\
\text { titis knuckles and ulnar borders } \\
\text { both hands, R. }>\text { L. }\end{array}$ & 6 months + & 2 weeks \\
\hline 6 & 46 & 11 & $\begin{array}{l}\text { Contact dermatitis from oil for } \\
4 \text { years. Clear for } 25 \text { years }\end{array}$ & $\begin{array}{c}\text { Once } \\
\text { (Radiant) }\end{array}$ & 2 days & $\begin{array}{l}\text { Onset with irritation on backs of } \\
\text { hands }+; 10 \text { days later blister- } \\
\text { ing and swelling of proximal } \\
\text { phalanges, R. }>\text { L. Palms } \\
\text { also involved }\end{array}$ & 7 weeks + & 1 week \\
\hline 7 & 47 & 3 & None & $\begin{array}{c}\text { 3-4 times } \\
\text { (Ariel) }\end{array}$ & $7-10$ days & $\begin{array}{l}\text { Irritation of hands }+++ \text { with } \\
\text { blistering. Dermatitis distal } \\
\text { third of dorsum of hands and } \\
\text { fingers }\end{array}$ & 13 weeks + & None \\
\hline 8 & 54 & 16 & None & $\begin{array}{l}\text { Twice } \\
\text { (Ariel) }\end{array}$ & 7 days & $\begin{array}{l}\text { nngers } \\
\text { Onset with irritation }++ \text {; later } \\
\text { swelling and blistering of } \\
\text { fingers. Dermatitis dorsum of } \\
\text { hands, knuckles, and proximal } \\
\text { phalanges, } R .>\text { L. }\end{array}$ & 8 weeks + & 3 weeks \\
\hline 9 & 51 & 10 & None & $\begin{array}{l}\text { 4-5 times } \\
\text { (Ariel) }\end{array}$ & $7-10$ days & $\begin{array}{l}\text { Irritation }++ \text { with fissuring. } \\
\text { Dermatitis distal third of } \\
\text { dorsum of hands and proximal } \\
\text { nhalanges }\end{array}$ & 7 weeks + & None \\
\hline 10 & 52 & 2 & None & $\begin{array}{l}3-4 \text { times } \\
\text { (Ariel and } \\
\text { Radiant) }\end{array}$ & 2 weeks & $\begin{array}{l}\text { phalanges } \\
\text { Irritation and swelling of hands } \\
++R \text {. hand mainly involved. } \\
\text { Patchy dermatitis dorsum of }\end{array}$ & 7 weeks + & None \\
\hline 11 & 53 & 1 & None & $\begin{array}{l}3 \text { times } \\
\text { (Ariel) }\end{array}$ & 2 weeks & $\begin{array}{l}\text { fingers } \\
\text { Irritation and swelling of fingers } \\
+++ \text { Dermatitis of distal } \\
\text { third of dorsum of hands and } \\
\text { proximal phalanges }\end{array}$ & 6 weeks + & 2 weeks \\
\hline 12 & 52 & 4 & None & $\begin{array}{l}4-5 \text { times } \\
\text { (Ariel and } \\
\text { Radiant) }\end{array}$ & 2-3 weeks & $\begin{array}{l}\text { Onset with irritation }++ \text { fol- } \\
\text { lowed by swelling and fis- } \\
\text { suring. Dermatitis of dorsum } \\
\text { of fingers and distal third of } \\
\text { hands. L. }>\text { R. }\end{array}$ & 5 weeks + & 1 week \\
\hline
\end{tabular}

The reagents were occluded with Airstrip Elastoplast (microporous plastic wound dressing), the results being read at 48 and 96 hours (Cases 2 and 4-12) or at 72 hours (Cases 1 and $3)$. All these tests were negative.

In two patients who had intermittently worn rubber gloves (Cases 1 and 9) additional tests were carried out with $1 \%$ tetramethylthiuram monosulphide and 1\% 2-mercaptobenzthiazole, each in yellow soft paraffin. Yellow soft paraffin was used as a control. One case originally included in the series had a positive reaction to tetramethylthiuram monosulphide and was excluded.

\section{Survey}

To determine the extent to which enzyme detergents were used and the number of cases of hand dermatitis, a questionary was issued to the 314 home helps employed by the City, and $310(98.7 \%)$ completed questionaries were returned. The relevant results are shown in Table II.

The 21 cases of dermatitis in group B were subsequently examined. Twelve ascribed their symptoms to using conventional detergents, two to disinfectants, and three to no known factor. Four related their symptoms to using enzyme deter- gents, but their clinical features did not merit inclusion in group A.

None of these 21 women had been off work as a result of hand dermatitis except one who, as well as conventional detergents, had used an enzyme detergent and was subsequently off work for nine weeks. Sickness records over the past five years showed that before the introduction of enzyme detergents there was a loss of time from work because of hand dermatitis in five home helps for a total period of 15 weeks, whereas 8 of the 12 patients in group A were on sick leave for a total of 45 weeks. 


\section{Discussion}

The home help service constitutes a group of people whose domestic work in the community involves the use of a wide variety of washing powders and an amount of wet work possibly in excess of that for the average housewife. From the results of the survey in this particular group the incidence of dermatitis would appear to be $6.8 \%$, with $3.9 \%$ additional cases which can be related to the recent introduction of enzyme detergents. The series of 12 cases represents $5 \%$ of 238 home helps using them, who in the past had been able to tolerate conventional detergents. It is difficult to estimate the true incidence of hand dermatitis from figures based on questionaries. In a recent survey of hand dermatoses in southern Sweden 107,206 persons above the age of 10 years were questioned. Hand dermatitis occurred in $1.2 \%$ of this population, and $66 \%$ of those with hand dermatitis were examined. A subsequent field survey, however, showed that only half of those with hand dermatoses had indicated this in their replies (Agrup, 1969).

The recent remarkable increase in sick leave due to dermatitis among home helps in Nottingham compared with the incidence over the previous five-year period would seem to indicate the severity of dermatitis following the use of enzyme detergents. A characteristic clinical picture emerged from a study of these 12 cases. Intense irritation and oedema occurred in Cases 1-6 within a few hours of a single exposure to the enzyme detergent, and this was followed by vesiculation and blistering. In Cases 7-12 the detergent had been used more than once and the rash developed in one to three weeks.

The 12 patients in the series (Table I) had been engaged in the home help service from 1 to 16 years (mean 7 years)-nine without previous skin trouble. Three cases with dermatitis in the past had safely used conventional detergents and were free from skin disease at the time of this outbreak, yet within three to six hours (Cases 3 and 4 ) and two days (Case 6) following the use of enzyme detergents they developed swelling and blistering of the hands. In Case 5 the dermatitis recurred five months later, with similar clinical features when a different enzyme detergent was used. This tendency to recurrence was noted in a patient, not in this series, seen at the outpatient clinic with hand dermatitis following the use of Ariel. A "blind" usage test of Ariel without the enzyme and then Ariel with the enzyme led to a recurrence of dermatitis in three days when Ariel with the enzyme was used. With the exception of Case 7 , the quantity of detergent used was stated to be no more than that recommended by the manufacturers. The wearing of gloves appears to provide protection, and this is supported by the observation that the only patient in the series (Case 3 ) who had worn plastic gloves when using an enzyme detergent developed dermatitis after immersing her hands so deeply in the detergent solution that it came in contact with the skin.

The negative patch tests with the detergents in $0.1 \%$ dilu- tion are probably of no significance, as they do not reproduce the conditions under which they were used. It would seem that patch tests are of limited value when a primary irritant, as in this case, is concerned. Patch tests with a variety of allergens might have helped to establish the aetiology in some of the 21 cases of hand dermatitis not ascribed to the enzyme detergents met with in the survey (group B, Table II). The survey showed in group B 12 cases of hand dermatitis which were ascribed to the use of conventional detergents. They seemed to have housewife's dermatitis and were unable to use one or more of the conventional detergents. Its features were mild compared with the severe reaction seen in most of thc cases in group A following the use of enzyme detergents. No other primary irritant or allergen could be held responsible in any of the cases in group $\mathrm{A}$.

The factors thought to be operative in producing housewife's dermatitis are complex and not fully understood. The influence of detergents on the skin $p H$, surface lipids, the keratin, and water permeability is possibly of relevance. Conventional detergents affect the keratin by breaking the sulfhydryl bonds (Van Scott and Lyon, 1953). Ariel contains, in addition to the ingredients found in most of the conventional detergents, a protease derived from the action of Bacillis subtilis on a protein-containing stock. The enzyme may possibly have a proteolytic effect on the keratin and the cytoplasmic proteins in the epidermis. It may be postulated that this is the basis of the irritant effect, though at present there is no evidence of its mode of action. Contact dermatitis due to an optical brightener in washing powders has recently been reported from Denmark (Osmundsen, 1969). This fluorescer, however, is not in use in Britain.

\section{Conclusion}

Twelve home helps out of 238 who had used conventional detergents with impunity for many years have, since the introduction of enzyme detergents, suffered from an intense irritation, blistering, and oedema of hands. It is submitted that in occupations where a considerable amount of wet work is undertaken enzyme detergents should be used with caution, as the enzyme even in a low concentration may act as a primary irritant.

We are grateful to Dr. Wilfrid H. Parry, Medical Officer of Health for the City of Nottingham, and to Dr. D. I. McCallum, consultant dermatologist, Nottingham General and City Hospitals, for their helpful advice and criticism.

REFERENCES

Agrup, G. (1969). Acta Dermato-Venereologica, 49, Suppl. No. 61. Osmundsen, P. E. (1969). British fournal of Dermatology, 81, 799.

Van Scott, E. J., and Lyon, J. B. (1953). Fournal of Investigative Dermatology, 2i, 199. 